\title{
Genetic Relationships among Slovenian Pears Assessed by Molecular Markers
}

\author{
Metka Sisko ${ }^{1}$ \\ Faculty of Agriculture and Life Sciences, University of Maribor, Pivola 10, 2311 Hoce, Slovenia \\ Branka Javornik \\ Department of Agronomy, Biotechnical Faculty, University of Ljubljana, Jamnikarjeva 101 Ljubljana, \\ 1000 Slovenia \\ Aleksander Siftar and Anton Ivancic \\ Faculty of Agriculture and Life Sciences, University of Maribor, Pivola 10, 2311 Hoce, Slovenia
}

\begin{abstract}
Additional Index words. Pyrus, perry, genetic diversity, AFLP, SSR
Abstract. A sample of 94 pear (Pyrus L.) genotypes, traditionally present in the Slovenian landscape, was analyzed by amplified fragment length polymorphism (AFLP) and SSR (SSR), focusing on the assessment of genetic relationships. The analyzed samples involved germplasm of Pyrus communis L., P. nivalis Jacq., and P. pyraster L. The AFLP technique, using five EcoRI and MseI primer combinations, revealed molecular polymorphism at a level of $65.95 \%$, representing 93 polymorphic bands among the total of 141 scored. With SSR analysis, 64 polymorphic alleles were found at seven microsatellite loci, with an average of 9.14 alleles per locus. Genetic distances among the individuals being studied were calculated using the Dice coefficient of similarity, and a dendrogram supported by AFLP and SSR data was constructed using the neighbor-joining method. The clustering method grouped the analyzed genotypes into three main clusters. The first cluster included the $P$. communis germplasm. The genotypes resembling $P$. nivalis were grouped in the second largest cluster, which could be divided in to four subclusters. The germplasm of $P$. pyraster, in this cluster, was found to be much less distinct than we had assumed. The most typical cultivar group in the third cluster was 'Vinska Mostnica'. The study indicated that $P$. nivalis germplasm is frequently present in Slovenia, but not as a pure species.
\end{abstract}

Pears belong to the family Rosaceae, subfamily Maloideae, and genus Pyrus. According to Challice and Westwood (1973), the most important pear species are distributed in five main groups: European species (P. communis, P. cordata Desv., and $P$. nivalis), West Asian species (P. amygdaliformis Vill., P. elaeagnifolia Pall., P. syriaca Boiss., P. glabra Boiss., $P$. regelii Rehd., and $P$. salicifolia Pall.), North African species ( $P$. longipes Coss. et Dur., P. mamorensis Trab., and $P$. gharbiana Trab.), Asian pea pears ( $P$. betulifolia Bunge, $P$. calleryana Decne., $P$. dimorphophylla Makino, $P$. fauriei Schneid., and P. koehnei Schneider), and medium-large fruited Asian pears ( $P$. hondoensis Kik. et Nak., P. pyrifolia Nak., P. ussuriensis Maxim., and P. pashia D. Don.).

Perry pears or Mostnica genotypes are often present in Slovenia. The term "perry pear" is a technological name, closely associated with the production of alcoholic drinks. They are mostly grafted trees, but some of them originated directly from seed. At present, 50 to 60 cultivars of perry pears can be found, including local cultivars (limited to one or two villages), subregional cultivars (present in wider areas) and cultivars spread across borders (in other parts of central Europe). Today, these pears have a relatively low economic value, but owing to their perfect adaptation to existing ecological conditions and resistance/tolerance to some diseases and pests, they may represent an important resource for organic production of juice and other drinks such as perry. In the 18th and 19th centuries, fruit from perry pear trees played an important role in the

Received for publication 29 July 2008. Accepted for publication 3 Nov. 2008. ${ }^{1}$ Corresponding author. E-mail: metka.sisko@uni-mb.si. nutrition of the poor rural population. In the past, farmers made use of all fruit grown on their land. Fruit were fresh eaten, used as animal feed, dried, cooked, baked, stored for winter or used for production of juice, fruit wine, vinegar, or brandy. In the last decades, this traditional usage of fruit has been abandoned. Large fruit trees, such as perry pears, became remnants of traditional agriculture; in majority without their primary function (grown as fruit trees). In most cases, fruit were left to decompose and/or as food for wild animals (Siftar, 2008). Farmers rarely rejuvenate them and their number is decreasing rapidly. The most important species among pears in Slovenia is $P$. communis; others include $P$. pyraster, $P$. nivalis, and $P$. amygdaliformis. According to some authors (Jogan et al., 2001), P. nivalis is the rarest pear species in Slovenia (Fig. 1B). As far as we know, the presence of $P$. nivalis as a "pure" species (described by Jacquin, 1774) has not yet been established. However, there are numerous cultivars that resemble it. The evolution of perry pears probably involved three species: P. communis, P. pyraster, and P. nivalis (A. Siftar, personal communication). The fruit are distinguished by juicy fruit containing a high concentration of fruit acids and tannins that stabilize drinks and make them clean and transparent. In this way, perry remains drinkable for a longer period of time. The most typical characteristics of $P$. communis: a broad-pyramidal tree up to $15 \mathrm{~m}$ high, rarely to $20 \mathrm{~m}$, sometimes spiny; young sprouts are glabrous or slightly pubescent, leaves are orbicularovate to elliptic, acute or short-acuminate, subcordate to broadcuneate and 2 to $8 \mathrm{~cm}$ long; petioles slender, 1.5 to $5 \mathrm{~cm}$ long; inflorescences villous or nearly glabrous; flowers about $3 \mathrm{~cm}$ across, 6 to 9 flowers per inflorescence; pedicels 1.5 to $3 \mathrm{~cm}$ 

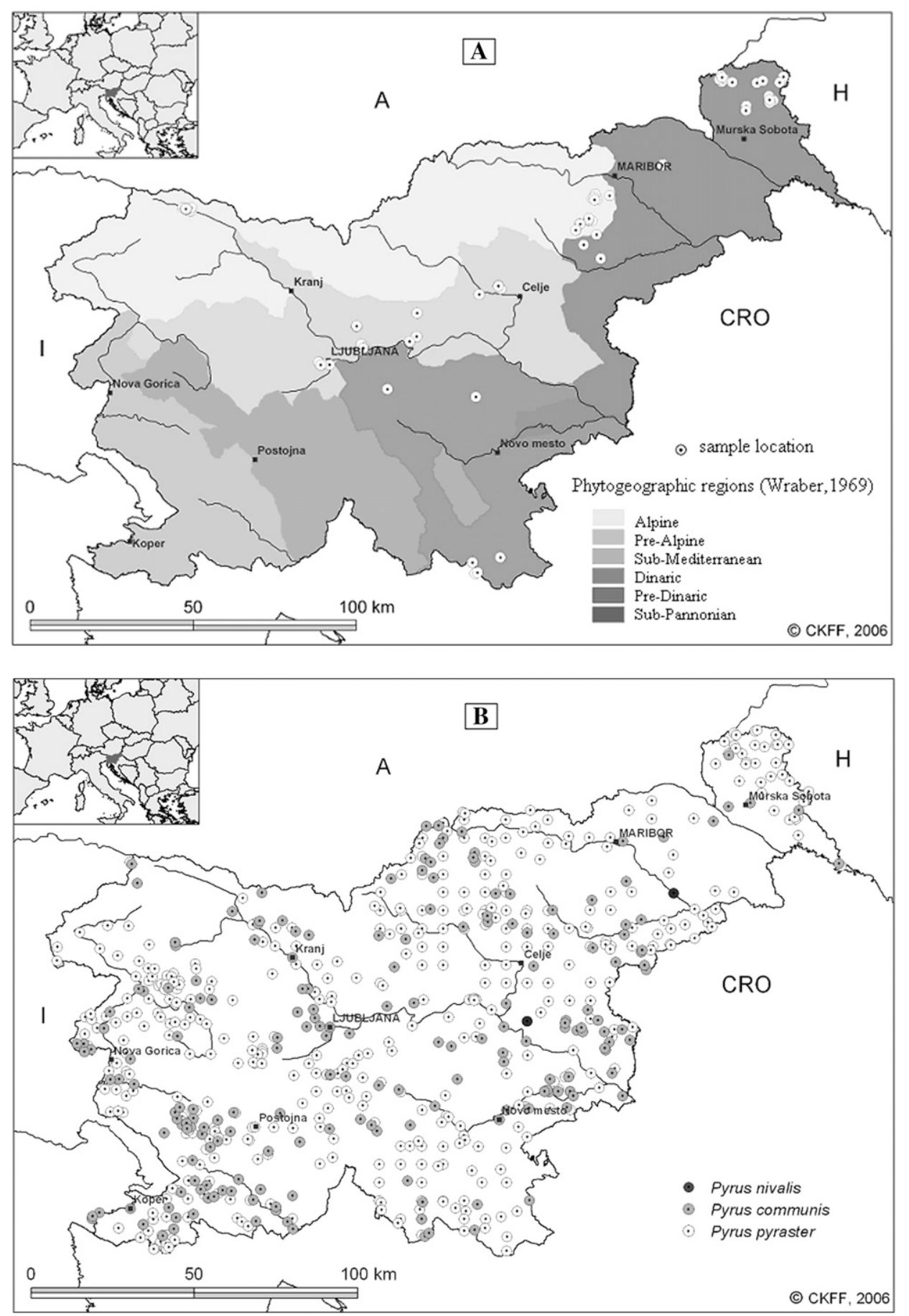

Fig. 1. Locations of Pyrus trees included in the study of genetic relationship (A); because of the high number of trees sampled, some of the locations on the map are overlapping. Localities of Pyrus communis, P. nivalis, and $P$. pyraster in Slovenia according to Jogan et al. (2001) (B). The maps were created with the help of the CKFF (Center za kartografijo favne in flore, Slovenia); I = Italy, A = Austria, $\mathrm{H}=$ Hungary, $\mathrm{CRO}=$ Croatia.

usually thorny, flowers 2 to $2.5 \mathrm{~cm}$ across, fruit 1.5 to $3 \mathrm{~cm}$ across (Rehder, 1940).

Perry pears are genetically and morphologically very heterogeneous. Besides the many characteristics of cultivated genotypes of $P$. communis, they have several characteristics of wild species; the fruit are generally smaller, sour or bitter, and generally contain more seeds. They can be classified in various ways, the most appropriate of which appears to be according to the dominant germplasm of $P$. communis, $P$. nivalis, or $P$. pyraster. In the evolution of perry pears, $P$. nivalis probably played a much more important role than $P$. pyraster. According to our experience, $P$. nivalis trees are much more allogamous and, therefore, participated in more genetic recombination than $P$. pyraster. This may also be one of the reasons that pure $P$. nivalis germplasm is hard to find.

Perry pears are probably much younger than traditional cultivars of $P$. communis and Vitis vinifera $\mathrm{L}$. The first selection was most likely aimed at creating genotypes that could be used as food. As they are extensively cultivated at higher elevations where $V$. vinifera cannot grow, we can assume that they were purposely selected for the production of alcoholic drinks.

Early efforts to identify cultivars by means of phenotypic data (Westwood, 1982) proved to be reliable only for a limited number of cultivars under certain conditions. The phenotypic variability seen among accessions grown in areas with slightly different environments and production practices demonstrates a number of problems associated with this approach (Hokanson et al., 1998). Owing to the high variability of morphological, anatomical, and/ or physiological characteristics, conclusions about relatedness between genotypes based on phenotypic markers are not always reli-

long; fruit turbinate or subglobose, on a slender stalk to $5 \mathrm{~cm}$ long; P. nivalis: a thornless tree, up to $16 \mathrm{~m}$, young sprouts tomentose; leaves elliptic to obovate, acute, cuneate, 5 to $8 \mathrm{~cm}$ long and 2 to $4 \mathrm{~cm}$ broad, white tomentose when young, finally glabrous above; petioles 1 to $3 \mathrm{~cm}$ long; inflorescence white tomentose with an average of 10 flowers per inflorescence, flowers 3 to $4 \mathrm{~cm}$ across, fruit subglubose to $5 \mathrm{~cm}$ across yellowish green; a stalk as long or longer than fruit; $P$. pyraster able. More appropriate are molecular markers, which appear to be more stable.

In the genus Pyrus, several studies have been carried out using molecular markers to characterize different genotypes and to establish the genetic relationships among species and/or genotypes. The earliest studies associated with the identification of Pyrus cultivars involved isozymes (Cerezo and Socias, 1989; Santamour and Demuth, 1980). Later studies involved 
Table 1. Identification and phenotype of the 94 sampled pears included in the study of genetic relationships.

\begin{tabular}{|c|c|c|c|c|c|c|c|}
\hline $\mathrm{D}^{\mathrm{z}}$ & Pyrus species & Accession name ${ }^{\mathrm{y}}$ & $\begin{array}{l}\text { Pubescence } \\
\text { intensity } \\
\text { of young shoots } \\
(1-3 \text { scale })^{\mathrm{x}}\end{array}$ & $\begin{array}{l}\text { Position of fruit } \\
\text { maximum } \\
\text { diam } \\
(1-3 \text { scale })^{\mathrm{w}}\end{array}$ & $\begin{array}{l}\text { Size of fruit } \\
(1-5 \text { scale })^{v}\end{array}$ & $\begin{array}{l}\text { Fruit profile } \\
\text { of sides } \\
(1-9 \text { scale })^{\mathrm{u}}\end{array}$ & $\begin{array}{c}\text { Time of } \\
\text { maturity for } \\
\text { consumption/ } \\
\text { processing } \\
(1-5 \text { scale })^{t}\end{array}$ \\
\hline 80 & P. communis & $\mathrm{PP}$ & 1 & 3 & 2 & 7 & 4 \\
\hline 48 & P. communis & PP & 1 & 1 & 1 & 2 & 2 \\
\hline 41 & P. communis & 'Gelbmostler' ('Rumenka'), PP & 1 & 2 & 3 & 1 & 2 \\
\hline 60 & P. communis & 'Gelbmostler' ('Rumenka'), PP & 1 & 2 & 3 & 1 & 2 \\
\hline 97 & P. communis & 'Doyene de Julliet' (Julijska Lepotica) & 1 & 2 & 1 & 2 & 1 \\
\hline 11 & P. communis & 'Kleine Landbirne' (Dunjacka), PP & 1 & 1 & 2 & $1-2$ & 4 \\
\hline 14 & P. communis & 'Kleine Landbirne' (Dunjacka), PP & 1 & 1 & 2 & $1-2$ & 4 \\
\hline 23 & P. communis & 'Kleine Landbirne' (Dunjacka), PP & 1 & 1 & 2 & $1-2$ & 4 \\
\hline 28 & P. communis & 'Kleine Landbirne' (Dunjacka), PP & 1 & 1 & 2 & $1-2$ & 4 \\
\hline 40 & P. communis & 'Kleine Landbirne' (Dunjacka), PP & 1 & 1 & 2 & $1-2$ & 4 \\
\hline 83 & P. communis & 'Laprsica' - LN, PP & 1 & 1 & 3 & 2 & 4 \\
\hline 89 & P. communis & 'Laprsica' - LN, PP & 1 & 1 & 3 & 2 & 4 \\
\hline 90 & P. communis & 'Laprsica' - LN, PP & 1 & 1 & 3 & 2 & 4 \\
\hline 96 & P. communis & 'Packham's Triumph' & 1 & 1 & 5 & 1 & 4 \\
\hline 10 & P. communis & 'Speckbirne' ('Vinska Mostnica'), PP & 1 & 2 & 4 & 1 & 4 \\
\hline 15 & P. communis & 'Speckbirne' ('Vinska Mostnica'), PP & 1 & 2 & 4 & 1 & 4 \\
\hline 27 & P. communis & 'Speckbirne' ('Vinska Mostnica'), PP & 1 & 2 & 4 & 1 & 4 \\
\hline 29 & P. communis & 'Speckbirne' ('Vinska Mostnica'), PP & 1 & 2 & 4 & 1 & 4 \\
\hline 30 & P. communis & 'Speckbirne' ('Vinska Mostnica'), PP & 1 & 2 & 4 & 1 & 4 \\
\hline 34 & P. communis & 'Speckbirne' ('Vinska Mostnica'), PP & 1 & 2 & 4 & 1 & 4 \\
\hline 35 & P. communis & 'Speckbirne' ('Vinska Mostnica'), PP & 1 & 2 & 4 & 1 & 4 \\
\hline 42 & P. communis & 'Speckbirne' ('Vinska Mostnica'), PP & 1 & 2 & 4 & 1 & 4 \\
\hline 84 & P. communis & 'Speckbirne' ('Vinska Mostnica'), PP & 1 & 2 & 4 & 1 & 4 \\
\hline 16 & P. communis & $\begin{array}{l}\text { 'Unterlaibacher' } \\
\text { ('Ljubljanska Mostnica'), PP }\end{array}$ & 1 & 2 & 3 & 6 & 4 \\
\hline 99 & P. communis & $\begin{array}{l}\text { 'Williams Bon Chrétien' } \\
\text { ('Viljamovka') }\end{array}$ & 1 & 2 & $3-4$ & 3 & 3 \\
\hline 98 & P. communis & 'Zgodnja Dekanka' & 1 & $2-3$ & 2 & 8 & 1 \\
\hline 49 & P. communis & $\begin{array}{l}\text { 'Zieregger Mostbirne' } \\
\text { ('Cirinska moštnica'), PP }\end{array}$ & 1 & 1 & 2 & 5 & 4 \\
\hline 7 & P. communis & $\mathrm{PP}$ & 1 & 1 & 3 & 4 & 4 \\
\hline 13 & P. communis & PP & 1 & 1 & 3 & 1 & 4 \\
\hline 18 & P. communis & PP & 1 & 1 & 3 & 6 & 3 \\
\hline 19 & P. communis & PP & 1 & 1 & 3 & 6 & 3 \\
\hline 20 & P. communis & PP & 1 & 1 & 3 & 6 & 3 \\
\hline 21 & P. communis & PP & 1 & 1 & 3 & 6 & 3 \\
\hline 22 & P. communis & PP & 1 & 1 & 1 & 2 & 3 \\
\hline 25 & P. communis & PP & 1 & 1 & 3 & 6 & 3 \\
\hline 31 & P. communis & PP & 1 & 1 & 3 & 6 & 3 \\
\hline 36 & P. communis & PP & 1 & 1 & 3 & 6 & 3 \\
\hline 52 & P. communis & PP & 1 & 3 & 3 & 6 & 3 \\
\hline 53 & P. communis & PP & 1 & 1 & 3 & $2-5$ & 2 \\
\hline & P. communis & PP & 1 & 1 & 3 & 1 & 2 \\
\hline 64 & P. communis & PP & 1 & 1 & 2 & 6 & 1 \\
\hline & P. communis & PP & 1 & 1 & 2 & 7 & 1 \\
\hline 69 & P. communis & PP & 1 & 1 & 2 & 1 & 1 \\
\hline & P. communis & PP & 1 & 1 & 3 & 1 & 3 \\
\hline & P. communis & PP & 1 & 1 & 2 & 3 & 2 \\
\hline 85 & P. communis & $\mathrm{PP}$ & 1 & 1 & 1 & 2 & 2 \\
\hline 45 & P. communis & Tree with Viscum album, PP & 1 & 2 & 1 & $1-2$ & 3 \\
\hline 1 & P. communis & 'Speckbirne', ('Vinska Mostnica'), PP & 1 & 2 & 4 & $3-6$ & 4 \\
\hline & P. communis & $\begin{array}{l}\times P . \text { nivalis developed from } \\
\text { seed-seedling, PP }\end{array}$ & 2 & 1 & 1 & $1-2$ & 4 \\
\hline
\end{tabular}


Table 1. Continued.

\begin{tabular}{|c|c|c|c|c|c|c|c|}
\hline $\mathrm{D}^{\mathrm{z}}$ & Pyrus species & Accession name ${ }^{\mathrm{y}}$ & $\begin{array}{l}\text { Pubescence } \\
\text { intensity } \\
\text { of young shoots } \\
(1-3 \text { scale })^{\mathrm{x}} \\
\end{array}$ & $\begin{array}{l}\text { Position of fruit } \\
\text { maximum } \\
\text { diam } \\
(1-3 \text { scale })^{\mathrm{w}} \\
\end{array}$ & $\begin{array}{l}\text { Size of fruit } \\
(1-5 \text { scale })^{\mathrm{v}}\end{array}$ & $\begin{array}{l}\text { Fruit profile } \\
\text { of sides } \\
(1-9 \text { scale })^{\mathrm{u}}\end{array}$ & $\begin{array}{c}\text { Time of } \\
\text { maturity for } \\
\text { consumption/ } \\
\text { processing } \\
(1-5 \text { scale })^{\mathrm{t}}\end{array}$ \\
\hline 3 & P. nivalis & $\begin{array}{l}\text { 'Welsche Bratbirne' } \\
\text { (Koroška Mostnica), PP }\end{array}$ & 3 & 1 & 1 & 5 & 4 \\
\hline 44 & P. nivalis & 'Hirschbirne' (Bela tepka), PP & 3 & 2 & 2 & 7 & 4 \\
\hline 55 & P. nivalis & 'Steierische Scheibelbirne' (Dolicanka), PP & 3 & 1 & 1 & 2 & 4 \\
\hline 32 & P. nivalis & 'Welsche Bratbirne' (Koroska Mostnica), PP & 3 & 1 & 1 & 5 & 4 \\
\hline 43 & P. nivalis & 'Welsche Bratbirne' (Koroska Mostnica), PP & 3 & 1 & 1 & 5 & 4 \\
\hline 65 & P. nivalis & 'Welsche Bratbirne' (Koroska Mostnica), PP & 3 & 1 & 1 & 5 & 4 \\
\hline 81 & P. nivalis & 'Welsche Bratbirne' (Koroska Mostnica), PP & 3 & 1 & 1 & 5 & 4 \\
\hline 46 & P. nivalis & 'Sózókörte' (Šoza), PP & 3 & 1 & 1 & 5 & 4 \\
\hline 50 & P. nivalis & seedling & 3 & 1 & 1 & 6 & 4 \\
\hline 8 & P. nivalis & $\mathrm{PP}$ & 3 & 1 & 2 & $5-7$ & 4 \\
\hline 2 & P. nivalis & $\mathrm{PP}$ & 3 & 1 & $1-2$ & 5 & 4 \\
\hline 12 & P. nivalis & 'Steierische Scheibelbirne' (Dolicanka), PP & 3 & 1 & 1 & $2-5$ & 4 \\
\hline 17 & P. nivalis & 'Steierische Scheibelbirne' (Dolicanka), PP & 3 & 1 & 1 & $2-5$ & 4 \\
\hline 24 & P. nivalis & 'Crnivka', PP & 3 & 1 & 1 & 7 & 4 \\
\hline 26 & P. nivalis & 'Crnivka', PP & 3 & 1 & 1 & $2-5$ & 4 \\
\hline 33 & P. nivalis & $\mathrm{PP}$ & 3 & 1 & 1 & $2-5$ & 4 \\
\hline 37 & P. nivalis & $\mathrm{PP}$ & 3 & 2 & 1 & 1 & 4 \\
\hline 38 & P. nivalis & 'Welsche Bratbirne' (Koroska Mostnica), PP & 3 & 2 & 1 & 5 & 4 \\
\hline 54 & P. nivalis & $\mathrm{PP}$ & 3 & 1 & 1 & $1-5$ & 4 \\
\hline 56 & P. nivalis & PP & 3 & 2 & $1-2$ & $1-5$ & 5 \\
\hline 58 & P. nivalis & PP & 3 & 2 & $1-2$ & $1-5$ & 5 \\
\hline 75 & P. nivalis & PP & 3 & 2 & 1 & 7 & 4 \\
\hline 76 & P. nivalis & PP & 3 & 1 & 1 & 2 & 4 \\
\hline 77 & P. nivalis & $\mathrm{PP}$ & 3 & 1 & 1 & 7 & 4 \\
\hline 78 & P. nivalis & PP & 3 & 1 & 1 & 7 & 4 \\
\hline 5 & P. nivalis & $\mathrm{PP}$ & 3 & 1 & 1 & 2 & 4 \\
\hline 70 & P. nivalis & 'Betzelbirne', PP & 2 & 2 & 3 & 1 & 5 \\
\hline 71 & P. nivalis & 'Betzelbirne', PP & 2 & 2 & 3 & 1 & 5 \\
\hline 59 & P. nivalis & ‘Tepka’, PP & 3 & 1 & 2 & $1-2$ & 5 \\
\hline 88 & P. nivalis & ‘Tepka', PP & 3 & 1 & 2 & $1-2$ & 5 \\
\hline 91 & P. nivalis & ‘Tepka', PP & 3 & 1 & 2 & $1-2$ & 5 \\
\hline 92 & P. nivalis & f. austriaca & 2 & 1 & 1 & 5 & 4 \\
\hline 4 & P. pyraster & $\mathrm{PP}$ & 1 & 1 & 1 & 2 & 3 \\
\hline 9 & P. pyraster & PP & 1 & 1 & 1 & 2 & 3 \\
\hline 47 & P. pyraster & $\mathrm{PP}$ & 1 & 1 & 1 & 2 & 3 \\
\hline 57 & P. pyraster & 'Snopsarca' - LN, PP & 1 & 1 & $1-2$ & $1-2$ & 3 \\
\hline 61 & $P$. pyraster & $\mathrm{PP}$ & 1 & 1 & 1 & 5 & 3 \\
\hline 66 & P. pyraster & PP & 1 & 1 & 1 & 2 & 3 \\
\hline 67 & P. pyraster & PP & 1 & 1 & 1 & 2 & 3 \\
\hline 74 & P. pyraster & PP & 1 & 1 & 1 & 2 & 3 \\
\hline 79 & P. pyraster & PP & 1 & 1 & 1 & 7 & $3-4$ \\
\hline 82 & P. pyraster & $\mathrm{PP}$ & 1 & 1 & 1 & 2 & 3 \\
\hline 87 & P. pyraster & PP & 1 & 1 & 1 & 2 & 3 \\
\hline 39 & P. pyraster & $\mathrm{PP}$ & 1 & 1 & 1 & 2 & 3 \\
\hline 6 & P. salicifolia & & 3 & 1 & 2 & 8 & 4 \\
\hline
\end{tabular}

${ }^{\mathrm{z} N u m b e r s}$ refer to the labels of Fig. 5 .

${ }^{\mathrm{y}} \mathrm{PP}=$ perry pear, $\mathrm{LN}=$ local name.

${ }^{\mathrm{x}} 1$ = weak, 2 = medium, 3 = strong [No. 14; International Union for the Protection of new Varieties of Plants (UPOV), 2000].

${ }^{\mathrm{w}} 1$ = in middle, 2 = slightly toward calyx, 3 = clearly toward calyx (No. 40; UPOV, 2000).

${ }^{v}$ Length $\times$ width: 1 = very small, 2 = small, 3 = medium, 4 = large, $5=$ very large $($ No. 41 ; UPOV, 2000); this parameter was adjusted according to Schmidthaler (2001).

${ }^{\mathrm{u}} 1$ = blunt-whirling, 2 = round, $3=$ bell shaped, $4=$ barrel shaped, $5=$ round-flat, $6=$ whirling, $7=$ ovoid, $8=$ bottle shaped, $9=$ drop shaped $($ No. 43; UPOV, 2000); this parameter was adjusted according to Schmidthaler (2001).

' 1 = very early 'Doyenné de Juillet', 2 = early 'Précoce de Trevoux', 3 = medium 'Coscia', 4 = late 'Beurré Hardy', 'Doyenné du Comice', 'Jeanne d'Arc', 5 = very late 'Doyenné d'Hiver', 'Nordhäuser, Winterforelle', 'Président Drouard' (No. 65; UPOV, 2000). 
RAPD markers, which were often used for diversity analyses in pears (Botta et al., 1998; Lee et al., 2004; Oliveira et al., 1999; Teng et al., 2002). The majority of the most recent studies are based on AFLP markers (Monte-Corvo et al., 2000, 2002; Shengua et al., 2002) for the identification and estimation of the genetic similarity among pear species and cultivars. Regarding SSR, Yamamoto et al. (2001), screened apple (Malus L.)derived microsatellite markers in 36 pear accessions belonging to five Pyrus species (one of which was $P$. communis) to evaluate their usefulness for pear characterization. Later, other authors screened more apple SSR markers for polymorphism in pears (Hemmat et al., 2003; Pierantoni et al., 2004). Yamamoto et al. (2002a and 2002b) were the first to develop SSR markers from $P$. pyrifolia, also known as asian pear. SSR markers are now frequently used for the assessment of genetic diversity in pears: Ghosh et al. (2006) screened 28 pear accessions (economically important cultivars and selections from breeding programs), mostly belonging to the species $P$. communis, with 18 SSR primer pairs; Volk et al. (2006) used 13 microsatellite loci for determination of relationships among 145 wild and cultivated individuals of $P$. communis; Wünsch and Hormaza (2007) identified 63 European pear cultivars with seven microsatellite loci. According to our knowledge, $\approx 90$ SSR markers are available now for genetic diversity studies within the genus Pyrus.

The main objectives of this study were to evaluate the genetic diversity and relationships among pears and to explain the taxonomic position of perry pears, which are the trees most typical of the Slovenian landscape, comparing them with the most common species such as $P$. communis, $P$. nivalis, and $P$. pyraster. To our knowledge, such research has not yet been conducted.

\section{Materials and Methods}

Plant material. A total of 94 Pyrus genotypes traditionally present in the Slovenian landscape were included in the study. The analyzed samples involved the germplasm of Pyrus communis, $P$. nivalis, and $P$. pyraster, which were collected in different parts of Slovenia (Fig. 1A). The exception is sample number 92 ( $P$. nivalis), which was collected in the Botanical Garden of the University of Vienna (Vienna, Austria). Most of the 94 samples collected included perry pears. As a reference, four commercial cultivars of $P$. communis (sample numbers 96-99), P. nivalis from the Botanical Garden of the University of Vienna, and $P$. pyraster from the Ljubljana Botanical Garden (Ljubljana, Slovenia) were included. A majority of the investigated accessions were determined according to the morphological descriptors published by Grill and Keppel, 2005; Handlechner and Schmidthalter, 2007; Hartmann, 2003; Kessler, 1948; Löschnig et al., 1912; Lucke et al., 1992; Petzold, 1982; Schmidthalter, 2001, and Terpó and Amaral Franco, 1968.

The studied genotypes are listed in Table 1. The grouping of perry pears is based on similarity to three crucial species: $P$. communis, $P$. nivalis, and $P$. pyraster (e.g., an accession was considered as a member of the $P$. nivalis perry pear group when characteristics of $P$. nivalis predominated). Accessions were grouped according to the visual survey of morphological traits (e.g., intensity of pubescence, fruit size and shape, and time of maturity for consumption). The fruit of these three common types of perry pears are shown in Fig. 2.
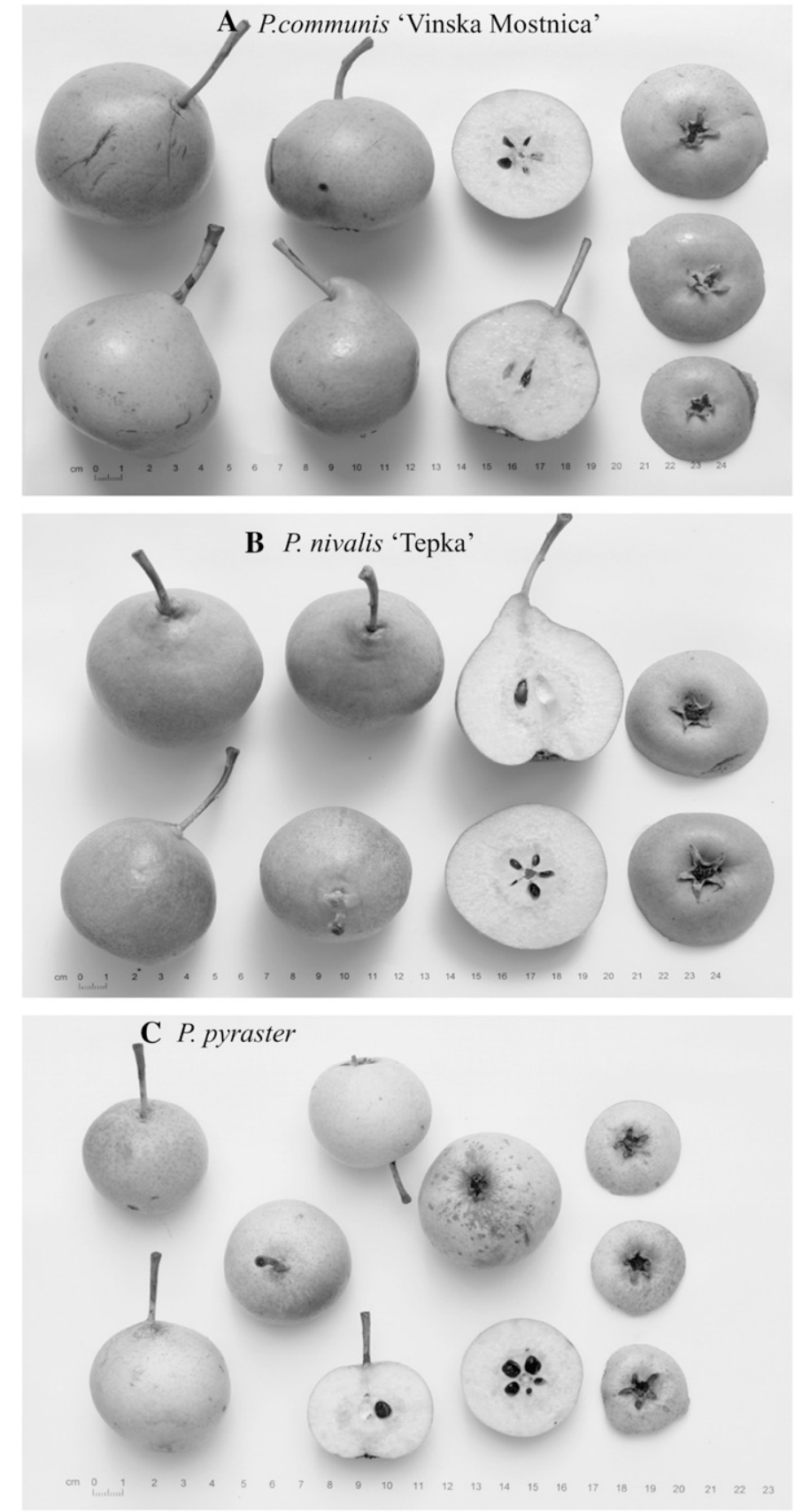

Fig. 2. Groups of perry pear fruit based on similarity to the three crucial species: Pyrus communis, $P$. nivalis, and $P$. pyraster.

DNA isolation. DNA was extracted from fresh, young leaves using the cetyl trimethylammonium bromide (CTAB) protocol. To $\approx 2$ to $3 \mathrm{~cm}^{2}$ of fresh leaf tissue, $1 \mathrm{~mL}$ of preheated $\left(68^{\circ} \mathrm{C}\right) \mathrm{CTAB}$ extraction buffer (Doyle and Doyle, 1987) was added and well homogenized with a mortar and pestle, and transferred to a $1.5-\mathrm{mL}$ tube. Samples were incubated for $1.5 \mathrm{~h}$ at $68{ }^{\circ} \mathrm{C}$ in a water bath. After incubation, $600 \mu \mathrm{L}$ of chloroform:isoamyl alcohol in a 24:1 proportion was added, and the samples were thoroughly mixed. The mixtures were centrifuged at $14.200 \mathrm{~g}_{\mathrm{n}}$ for 10 to $15 \mathrm{~min}$. After centrifugation, the supernatant was transferred to a fresh tube and the DNA was precipitated by the addition of 1 volume of $3 \mathrm{M}$ sodium acetate and 10 volumes of ice-cold isopropanol and kept at $-20^{\circ} \mathrm{C}$ for 
20 to $30 \mathrm{~min}$. Samples were again centrifuged at $14.200 g_{\mathrm{n}}$ for 10 to $15 \mathrm{~min}$. The pellet was washed in $70 \%$ ethanol for $20 \mathrm{~min}$, air dried, and rehydrated in $100 \mu \mathrm{L}$ of TE buffer. The DNA concentration was estimated using a DNA fluorometer TKO 100 (Hoefer, Holliston, MA). Two separate extractions per tree were performed.

Molecular ANALySIS. To obtain more reliable information, two types of molecular markers (AFLP and SSR) were used. We assumed that the use of different molecular marker systems could reveal more information about the existing polymorphism and therefore enable more reliable results.

AFLP MARKERs. The DNA was restricted using two restriction enzymes (EcoRI and MseI) and was ligated to EcoRI and MseI adapters. The total genomic DNA (500 ng) was incubated for $2 \mathrm{~h}$ at $37^{\circ} \mathrm{C}$ together with $2.5 \mathrm{U}$ of EcoRI and $2.5 \mathrm{U}$ of MseI restriction enzymes (New England Biolabs, Ipswich, MA) and buffer solution (50 mm NaCl, $100 \mathrm{~mm}$ Tris- $\mathrm{HCl}, 10 \mathrm{~mm} \mathrm{MgCl}_{2}$, and $0.025 \%$ Triton X-100, pH 5.59) in final volume of $40 \mu \mathrm{L}$. During the incubation, from time to time, samples were gently stirred. On the next day, $10 \mu \mathrm{L}$ of ligation solution [5 pmol $\cdot \mu \mathrm{L}^{-1}$ EcoRI-adapter, $50 \mathrm{pmol} \cdot \mu \mathrm{L}^{-1}$ MseI-adapter; $1 \times \mathrm{T} 4$ DNA ligase buffer $\left(50 \mathrm{~mm}\right.$ Tris- $\mathrm{HCl}, 10 \mathrm{~mm} \mathrm{MgCl}_{2}, 10 \mathrm{~mm}$ dithiotreitol, $1 \mathrm{~mm}$ ATP, and $25 \mu \mathrm{g} \cdot \mathrm{mL}^{-1} \mathrm{BSA}, \mathrm{pH} 7.5$, New England Biolabs, and 1 U of Weiss T4-DNA ligase] was added and kept incubated at the same temperature for another 2 to $3 \mathrm{~h}$. Preamplifications were performed in $50-\mu \mathrm{L}$ volumes of $1 \times$ PCR buffer, $1.5 \mathrm{mM} \mathrm{MgCl}_{2}, 0.2 \mathrm{~mm}$ dNTPs, $75 \mathrm{ng}$ of EcoRI and MseI primers, $1.5 \mathrm{U}$ of Taq polymerase, and $5 \mu \mathrm{L}$ of ligated DNA, using $72^{\circ} \mathrm{C}$ for $120 \mathrm{~s}$, followed by 20 cycles of $94^{\circ} \mathrm{C}$ for $30 \mathrm{~s}, 56^{\circ} \mathrm{C}$ for $60 \mathrm{~s}$, and $72^{\circ} \mathrm{C}$ for $105 \mathrm{~s}$. Two-microliter aliquots of the diluted (1:10) preamplification product were used as templates for the selective amplifications with five primer combinations: E-AGC + M-CTG, E-AGC + M-CAT, E-AGC + $\mathrm{M}-\mathrm{CTC}, \mathrm{E}-\mathrm{AGC}+\mathrm{M}-\mathrm{CTT}$, and E-AGC + M-CTA. These five combinations were chosen among 10 primer pairs previously tested on four samples. The five most polymorphic primers were used in the experiment. EcoRI primers were labeled with Cy5 at the $5^{\prime}$ end for selective amplification, thus permitting fluorescence detection. The selective amplification was carried out in a $10-\mu \mathrm{L}$ volume using the following temperature profile: $94{ }^{\circ} \mathrm{C}$ for $150 \mathrm{~s}$ followed by 13 cycles of $94^{\circ} \mathrm{C}$ for $30 \mathrm{~s}, 65^{\circ} \mathrm{C}$ for $30 \mathrm{~s}$, with a decrease of annealing temperature of $0.7^{\circ} \mathrm{C}$ per cycle, and $72{ }^{\circ} \mathrm{C}$ for $60 \mathrm{~s}$, followed by 23 cycles at the annealing temperature of $56{ }^{\circ} \mathrm{C}$. To the PCR products, equal volumes of formamide loading dye were added and denatured at $94{ }^{\circ} \mathrm{C}$ for 4 min. The samples were separated on a $7.5 \%$ polyacrylamide denaturing gel in an automated ALFexpressII sequencer
(Amersham Biosciences, Piscataway, NJ). A fluorescentlabeled size marker (Cy5 Sizer 50-500; Amersham Biosciences) was used as a molecular weight reference.

SSR MARKERS. Seventeen SSR loci developed earlier (Gianfranceschi et al., 1998; Guilford et al., 1997; Hokanson et al., 1998; Yamamoto et al., 2001, 2002b) were tested: KA4b, KA14, KA16, KB16, KU10, BGA35, BGT23b, GD15, CH01H10, CH02B10, CHO2D11, CH01F02, CH02B03b, CH01E12, O2B1, 05g8, and 28f4. Because some of the loci resulted in unspecific amplification and amplified more then one locus or because of the presence of a monomorphic allele, only seven of them were selected and used for further experimentation (Table 2).

Ten microliters of PCR mixture contained $20 \mathrm{ng}$ of DNA, $0.25 \mathrm{U}$ of Taq DNA polymerase (Promega, Madison, WI), reaction buffer $\left(50 \mathrm{~mm} \mathrm{KCl}, 1.5 \mathrm{~mm} \mathrm{MgCl}_{2}\right.$, and $10 \mathrm{~mm}$ Tris$\mathrm{HCl}$; Promega), $0.5 \mu \mathrm{L}$ of each primer, and $200 \mu \mathrm{M}$ of each dNTP. PCR conditions consisted of an initial denaturation at $94{ }^{\circ} \mathrm{C}$ for $5 \mathrm{~min}$, followed by 5 cycles of $94^{\circ} \mathrm{C}$ for $45 \mathrm{~s}, 60^{\circ} \mathrm{C}$ for $30 \mathrm{~s}$, with a decrease of annealing temperature of $1{ }^{\circ} \mathrm{C}$ per cycle, and $72{ }^{\circ} \mathrm{C}$ for $1 \mathrm{~min}$, followed by 25 cycles at the annealing temperature of $55^{\circ} \mathrm{C}$ and extension at $72^{\circ} \mathrm{C}$ for $90 \mathrm{~s}$, and a final step of $8 \mathrm{~min}$ at $72^{\circ} \mathrm{C}$. For the locus KB16, 32 cycles were used, and for locus $28 \mathrm{f} 4$ and $\mathrm{CHO} 1 \mathrm{H} 10$, only 25 cycles were used. The annealing temperatures were different for the locus KU10 $\left(58.6^{\circ} \mathrm{C}\right)$, BGA $35\left(56.7{ }^{\circ} \mathrm{C}\right), \mathrm{CH} 01 \mathrm{~F} 02\left(58.6{ }^{\circ} \mathrm{C}\right)$, and $28 \mathrm{f} 4$ $\left(55.8^{\circ} \mathrm{C}\right)$. The PCR was performed using a Gene AMP 9700 thermocycler (Applied Biosystems, Foster City, CA). PCR products were separated and detected on a $7.5 \%$ polyacrylamide denaturing gel in an automated ALFexpressII sequencer (Amersham Biosciences). A fluorescent-labeled size marker (Cy5 Sizer 50-500; Amersham Biosciences) was used as a molecular weight reference.

DATA ANALYSIS. AFLP and SSR data were analyzed using the software ALFwinTM Fragment Analyser 1.01 (Amersham Biosciences), which forms part of the computer equipment of the ALFexpres II sequencer. All unambiguous fragments were scored for the presence (1) or absence (0) of each band. Only clear and reproducible fragments were taken for data analysis. The binary data matrix was used to calculate Dice's similarity coefficients (Dice, 1945); $\mathrm{D}_{(i, j)}=(b+c) /[(2 a+(b+c)]$, where $\mathrm{D}_{(i, j)}$ is the similarity between two individuals $i$ and $j$; $a$ is the number of bands present in both $i$ and $j ; b$ is the number of bands present in $\mathrm{i}$ and absent in $j$; and $c$ is the number of bands present in $j$ and absent in $i$. The values of Dice's coefficients are between 0 (there is no common band) and 1 (two genotypes have identical markers, thus they are identical). Dice similarity

Table 2. SSR loci analyzed and parameters of genetic variability calculated for different microsatellite loci of the 94 pear genotypes: number of alleles $(n)$, effective number of alleles $\left(\mathrm{n}_{\mathrm{e}}\right)$, observed $\left(\mathrm{H}_{\mathrm{o}}\right)$ and expected $\left(\mathrm{H}_{\mathrm{e}}\right)$ heterozygosity, polymorphic information content $(\mathrm{PIC})$, and probability of identity (PI).

\begin{tabular}{llcccccc}
\hline Locus & \multicolumn{1}{c}{ Reference } & $\mathrm{n}$ & $\mathrm{n}_{\mathrm{e}}$ & $\mathrm{H}_{\mathrm{o}}$ & $\mathrm{H}_{\mathrm{e}}$ & PIC & PI \\
\hline KB16 & Yamamoto et al. (2002a) & 4 & 2.845 & 0.968 & 0.646 & 0.582 & 0.329 \\
KU10 & Yamamoto et al. (2002a) & 15 & 5.791 & 0.303 & 0.824 & 0.809 & 0.091 \\
BGA35 & Yamamoto et al. (2002a) & 4 & 1.776 & 0.538 & 0.430 & 0.389 \\
CH01H10 & Gianfranceschi et al. (1998) & 12 & 4.108 & 0.235 & 0.748 & 0.729 \\
CH01F02 & Gianfranceschi et al. (1998) & 10 & 5.428 & 1.000 & 0.815 & 0.797 & 0.161 \\
02B1 & Guilford et al. (1997) & 11 & 6.070 & 0.479 & 0.814 & 0.489 & 0.100 \\
28f4 & Guilford et al. (1997) & 8 & 3.841 & 0.793 & 0.738 & 0.711 \\
Avg & & 9.14 & 4.266 & 0.617 & 0.716 & 0.691 & 0.157 \\
\hline
\end{tabular}


coefficients were calculated using the DARWIN computer package (Perrier and Jacquemoud-Collet, 2005).

For each microsatellite locus, the number of alleles per locus $(n)$, allele frequencies, observed heterozygosity $\left(H_{O}\right)$, and expected heterozygosity $\left(H_{E}\right)$ were calculated using the 'IDENTITY 1.0' computer program (Wagner and Sefc, 1999). Also, the number of effective alleles $\left(n_{e}\right)$ (Morgante et al., 1994) was estimated using the following equation:

$$
\mathrm{n}_{\mathrm{e}}=\left(\sum_{i}^{n} p_{i}^{2}\right)^{-1}
$$

where $p$ is the frequency of the $i$-th allele and the polymorphism information content (PIC) (Botstein et al., 1980), a measure of the allelic diversity at a locus, was calculated using the program Cervus 2.0 (Marshall et al., 1998).

The average distance between pairs of accessions was obtained by taking into account microsatellite and AFLP data, and a neighbor-joining tree was constructed using the DARWIN computer package (Perrier and Jacquemoud-Collet, 2005).

A matrix of Dice similarity coefficients was used for assessing relationships among 94 genotypes using the neighborjoining algorithm developed by Saitou and Nei (1987).

\section{Results}

The five AFLP primer combinations (Table 3) amplified a total of 141 fragments in the 94 analyzed genotypes in sizes from 40 to $388 \mathrm{bp}$. Ninety-three bands were polymorphic, representing a $65.95 \%$ rate of polymorphism.

With the SSR analysis, 64 polymorphic alleles were found at seven microsatellite loci. The number of alleles (Table 2) detected per locus ranged from 4 (KB16, BGA35) to 15 , (KU10), with an average of 9.14 alleles per locus and 0.691 PIC value per locus. The effective number of alleles was calculated at 4.26 alleles. The observed heterozygosity ranged between 0.235 (locus CH01H10) and 1.00 (locus CH01F02), with an average of 0.617 . The expected heterozygosity ranged between 0.430 (locus BGA35) and 0.824 (locus KU10), with an average of 0.716 . The differences between the observed and expected heterozygosity were observed on all loci. The largest difference was observed on locus $\mathrm{CH} 01 \mathrm{H} 10(0.513)$ and the lowest on locus BGA35 (0.055). The average of observed $(0.617)$ and expected $(0.716)$ heterozygosity was very similar. The reliability of microsatellite markers in cultivar genotyping was determined on the basis of the following criteria: the complexity of the banding patterns, the amplification of quality PCR products, the stability of the microsatellite repeated structure, and the polymorphic information content of markers. On the basis of PIC values, all the microsatellite loci except BGA35 were classified as very informative loci (PIC $>0.5$ ), and five loci proved suitable for mapping (PIC $>0.7$ ).

The allele sizes, frequencies, and variability parameters calculated for each locus are shown in Tables 2 and 4. Figure 3 and 4 show examples of the obtained results for AFLP and SSR markers.

Both marker systems demonstrated a high level of genetic variability in these pear genotypes and proved their reliability in assessing genetic relationships.

The dendrogram (Fig. 5) based on joined AFLP and SSR data arranged the 94 samples under investigation in three main
Table 3. The total number of AFLP markers, number of polymorphic markers, and percentage of polymorphisms amplified in pear genotypes using five AFLP primer combinations.

\begin{tabular}{lccc}
\hline $\begin{array}{l}\text { Primer } \\
\text { combination }\end{array}$ & $\begin{array}{c}\text { Amplified } \\
\text { fragments } \\
\text { (no.) }\end{array}$ & $\begin{array}{c}\text { Polymorphic } \\
\text { fragments } \\
\text { (no.) }\end{array}$ & $\begin{array}{c}\text { Polymorphic } \\
\text { fragments } \\
(\%)\end{array}$ \\
\hline E-AGC + M-CTG & 30 & 24 & 80.00 \\
E-AGC + M-CAT & 44 & 30 & 68.18 \\
E-AGC + M-CTC & 21 & 11 & 52.38 \\
E-AGC + M-CTT & 25 & 17 & 68.00 \\
E-AGC + M-CTA & 21 & 11 & 52.38 \\
$\Sigma$ & 141 & 93 & 65.95 \\
\hline
\end{tabular}

clusters. When looking at the length of the lines, we observed a larger distance between accessions than between clusters. The within-cluster heterogeneity was much more expressed than the one between clusters.

The cluster I included $P$. communis germplasm. In this cluster, we found all four commercial cultivars of $P$. communis included in our research: Packham's Triumph, Doyene de Julliet, Zgodnja Dekanka, and Williams Bon Chretién, as well as an old cultivar group, Laprsica.

The subcluster contained the cultivar group Dunjacka, with sample numbers $23,11,14$, and 28 . This group of samples included sample 31, which was considered as an undefined cultivar of $P$. communis. Our molecular results suggest that this sample probably belongs to the cultivar group Dunjacka.

The genotypes resembling $P$. nivalis were grouped in the second cluster, which could be divided in to three sub-clusters. The sub-cluster 1 contained an unidentified group of Mostnica pears, characterized by the dominant $P$. nivalis germplasm. In this sub-cluster we also found some cultivars known as Betzelbirne, represented by samples 70 and 71 . In the same sub-cluster, there was also an old cultivar called Zimska Strdenka (numbers 46 and 50). Owing to their close positions in the cluster, we can assume that they belong to the same cultivar. The differences may be the consequence of an accumulation of mutations over a long time period.

In the subcluster 1 , we found three undefined genotypes of $P$. nivalis (samples 54, 56, and 58). Samples 52 and 53 were morphologically similar to $P$. communis. However, the molecular analyses showed that they occupied positions close to $P$. nivalis. The subcluster 3 was very small and contained only three samples of $P$. pyraster; the first was sample 9 from the Ljubljana Botanical Garden; the second was 39 (used as rootstock in the recently created pear tree lane in Kuzma, Slovenia), and the third was sample 57 from Ratkovci (northeastern Slovenia).

The most typical cultivar group in the cluster III is 'Vinska Mostnica'. This includes samples 34, 27, 30, 29, 35, 10, 1, 15, and 42.

When comparing the data obtained by molecular markers with the morphological characteristics listed in Table 1, one can observe that, in the cluster I, weakly expressed young shoot pubescence predominated (17 accessions of 23) and the position of the maximum fruit diameter was in the middle, indicating that fruit were round or nearly round (involving 18 accessions of this cluster). In this cluster, all fruit sizes can be found, from very small to very large. All accessions in the subcluster 'Dunjacka' exhibited weak young shoot pubescence, and the position of the maximum fruit diameter was in the 
Table 4. Allele size (bp) and allele frequencies (in parenthesis) of the 94 pear genotypes at seven microsatellite loci.

\begin{tabular}{|c|c|c|c|c|c|c|c|}
\hline \multirow[b]{2}{*}{ Alleles } & \multicolumn{7}{|c|}{ Locus } \\
\hline & KB16 & KU10 & BGA35 & CH01H10 & CH01F02 & 02B1 & $28 \mathrm{f} 4$ \\
\hline$\overline{\mathrm{A}}$ & $166(0.086)$ & $110(0.011)$ & $140(0.005)$ & $108(0.006)$ & $176(0.054)$ & $268(0.181)$ & $114(0.011)$ \\
\hline B & $168(0.398)$ & $118(0.045)$ & $142(0.198)$ & $120(0.154)$ & $180(0.125)$ & $270(0.096)$ & $116(0.098)$ \\
\hline $\mathrm{D}$ & $172(0.425)$ & $122(0.090)$ & $146(0.071)$ & $124(0.395)$ & $184(0.119)$ & $274(0.202)$ & $120(0.172)$ \\
\hline $\mathrm{E}$ & - & $124(0.185)$ & - & $126(0.247)$ & $186(0.038)$ & $276(0.149)$ & $122(0.437)$ \\
\hline $\mathrm{F}$ & - & $126(0.219)$ & - & $128(0.012)$ & $188(0.081)$ & $280(0.027)$ & $124(0.069)$ \\
\hline $\mathrm{H}$ & - & $130(0.067)$ & - & $132(0.019)$ & $194(0.025)$ & $284(0.016)$ & $130(0.017)$ \\
\hline I & - & $132(0.006)$ & - & $134(0.006)$ & $196(0.019)$ & $286(0.005)$ & - \\
\hline $\mathrm{J}$ & - & $134(0.051)$ & - & $138(0.006)$ & $202(0.006)$ & $292(0.005)$ & - \\
\hline K & - & $138(0.017)$ & - & $142(0.006)$ & - & $296(0.016)$ & - \\
\hline $\mathrm{L}$ & - & $144(0.006)$ & - & $146(0.012)$ & - & - & - \\
\hline M & - & $148(0.006)$ & - & - & - & - & - \\
\hline
\end{tabular}

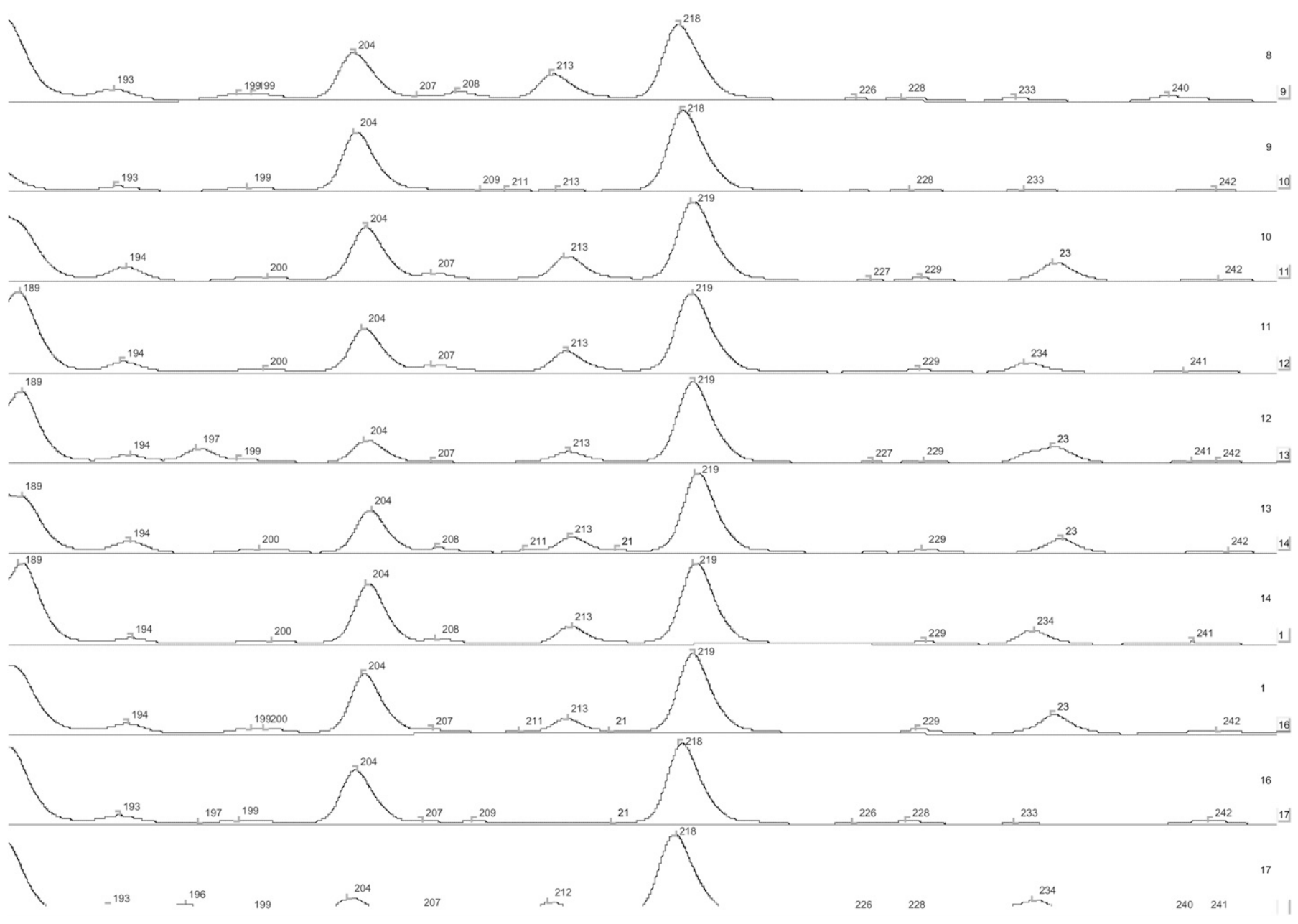

Fig. 3. An example of AFLP results for the primer combination E-AGC/M-CTG, using curve option. Above each detected peak, its size in bps is shown. Each row represents one sample of pear genotype (10 samples of 94 are presented). 


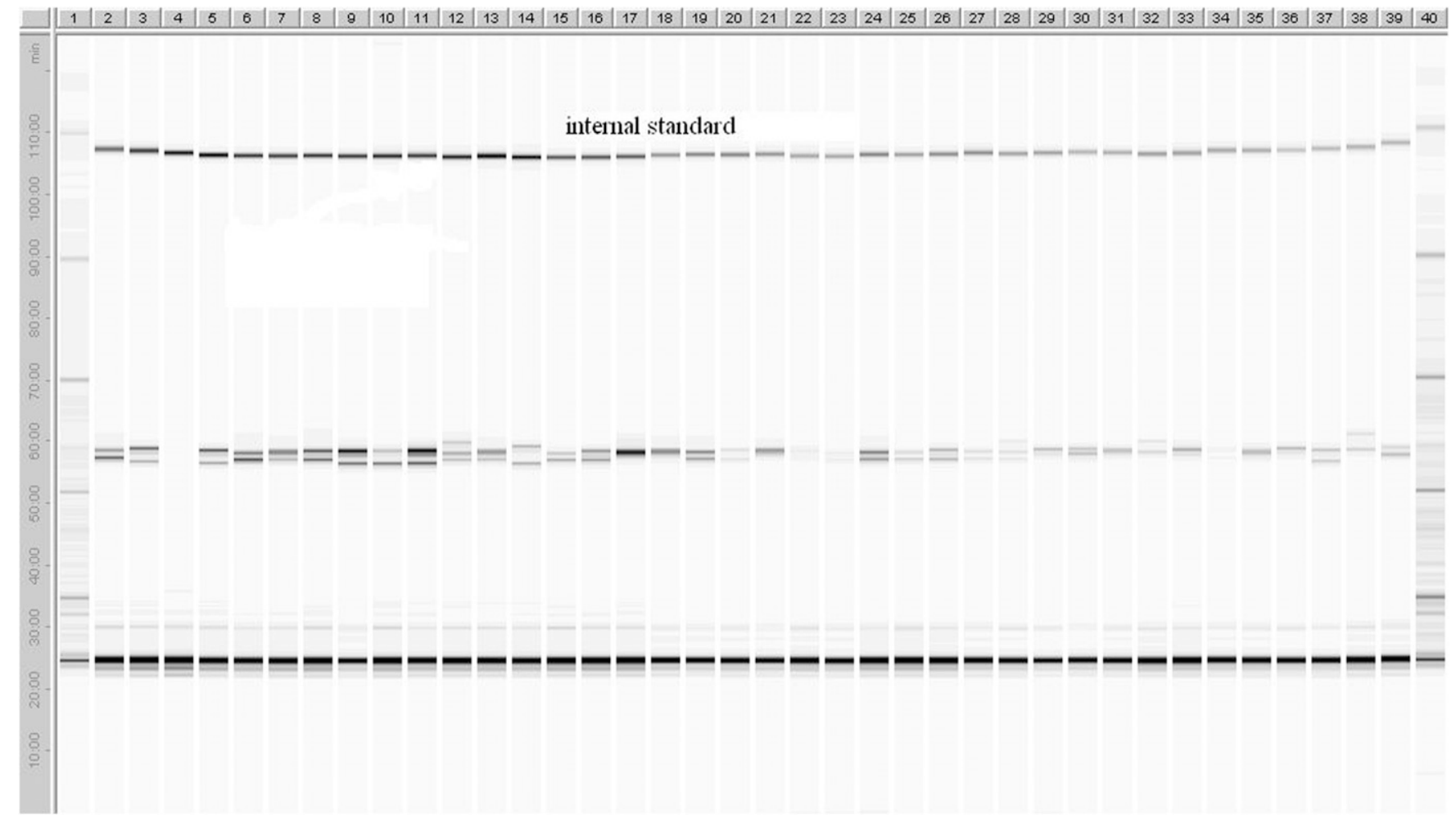

Fig. 4. Microsatellite alleles of 38 pear genotypes on locus $28 \mathrm{f} 4$. The first and the last column represent size marker standards (50-500 bp); columns 2 to 39 represent analyzed samples.

middle. Accessions in this subcluster were characterized by small fruit; the exception was the accession 31, which had medium fruit size. In the cluster II, subcluster 1, strong intensity of young shoot pubescence predominated (20 accessions of 25) and the position of the maximum fruit diameter was in the middle in 17 accessions in this subcluster. Fruit were mostly very small (17 accessions) and many different fruit profiles could be found. In the subcluster 2 (cluster II), weakly expressed young shoot pubescence predominated (15 accessions of 18) with the position of the maximum fruit diameter in the middle (15 accessions among 18). Sizes of fruit varied from very small to medium. Accessions in the subcluster 3 were morphologically very similar to those characterized by weakly expressed young shoot pubescence, the position of the maximum fruit diameter was in the middle, and fruit were very small and round in profile. In the subcluster 'Vinska Mostnica' (cluster III), all accessions exhibited weak young shoot pubescence, with the position of the maximum fruit diameter in the middle or slightly closer to calyx residual, with medium or large fruit and different side profiles. The last subcluster of the cluster III involved morphologically quite different accessions.

The accessions closely linked in the dendrogram are, in most cases, morphologically similar. For instance, accessions 23 and 11 that lie together in the dendrogram are identical in all studied morphological traits presented in Table 1. A similar conclusion can be made for several other accessions such as 70 and 71, 39 and 9,34 and 27, and 21 and 19 . Accessions 17 and 24,1 and 10, 2 and 3, 37 and 38, and 54 and 55 differ only in one trait: the fruit profile of sides.

The studied accessions were collected in different parts of Slovenia (Fig. 1A). The correspondence between the genetic structure and the geographical distribution indicates that some accessions from different geographical locations probably have a very similar genetic background because of their position in the same cluster or subcluster. As an example can be the accessions collected from Dovje (northwestern Slovenia), the distance of $\approx 240 \mathrm{~km}$, to Kuzma (northeastern Slovenia), which are placed in the same subcluster, named 'Vinska Mostnica'.

Within the cluster I, accessions 99, 97, 98, 89, 84, 80, 96, 23, $11,14,31$, and 28 were classified as $P$. communis; accessions 82 and 79 as $P$. pyraster; and $88,77,91,78,92$, and 8 as $P$. nivalis. In the subcluster 1 (cluster II), most accessions belonged to the $P$. nivalis group, with two exceptions: number 66, which belonged to $P$. pyraster and numbers 52 and 53, which belonged to $P$. communis. In the subcluster 2 (cluster II), accessions classified as $P$. communis predominated, with the exceptions 75 and 76, which were classified as $P$. nivalis, and $74,87,61,47$, and 67 , which were classified as $P$. pyraster. In the subcluster 3 (cluster II), all samples belong to $P$. pyraster. The subcluster 'Vinska Mostnica' (cluster III), was composed of $P$. communis genotypes. The most heterogeneous was the subcluster 2 (cluster III), with four $P$. communis, two $P$. nivalis, one $P$. pyraster, and one $P$. salicifolia tree. Here, we have to mention that in several cases, it was very difficult to position the perry pear accessions to appropriate species groups when the criteria were based solely on morphological markers.

\section{Discussion}

Efficient molecular research requires the selection of highly informative markers from the available molecular marker systems. Before the development of microsatellite markers in apples and pears, RAPD markers were extensively used for pear genome research. In our research, AFLP and SSR markers were 


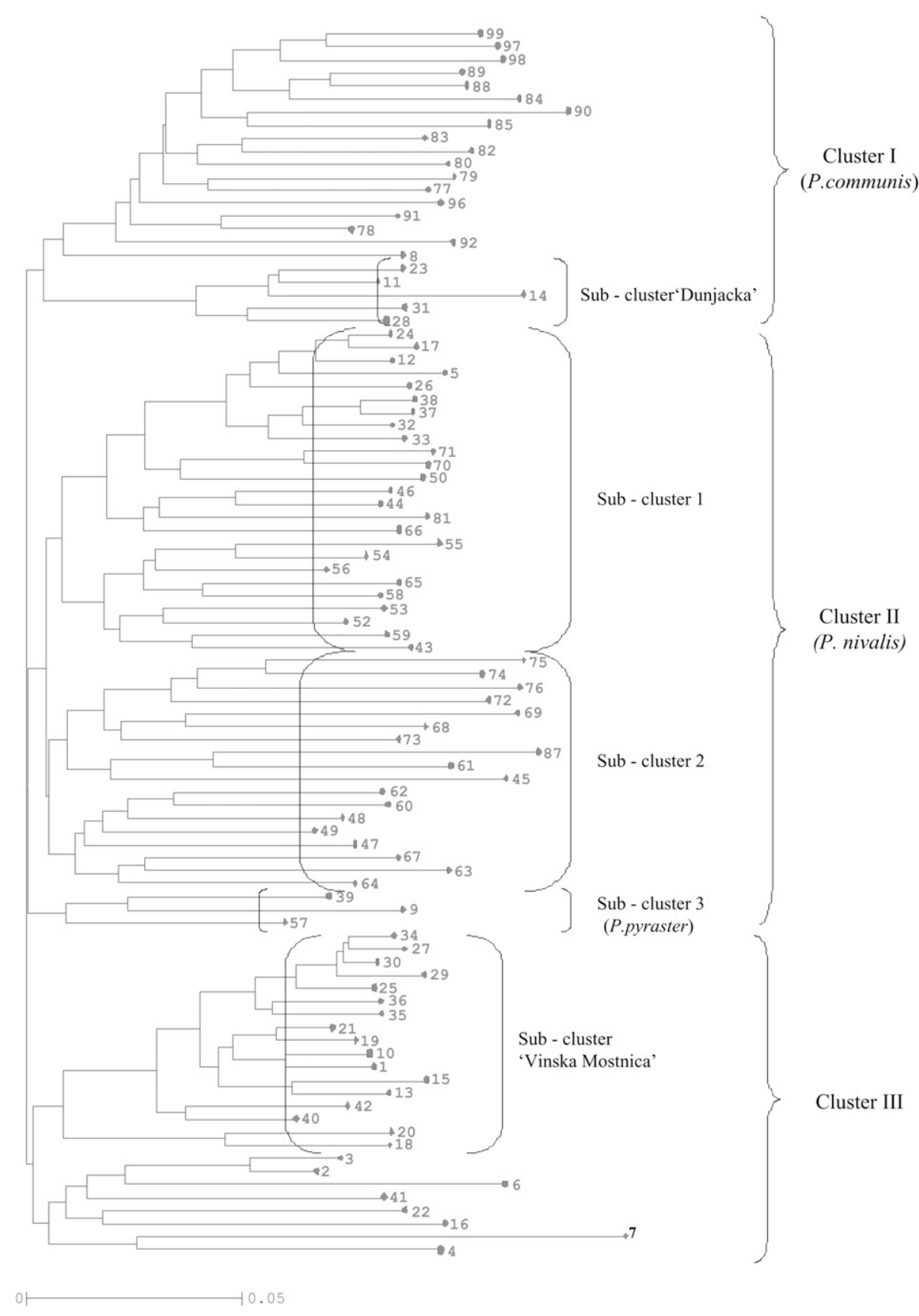

Fig. 5. Neighbor-joining dendrogram describing genetic relationships among 94 pear genotypes based on a combination of AFLP and SSR markers. Each genotype is represented by a number indicated in Table 1 .

with self-pollinating and/or annual crops, the average number of alleles per locus is lower and for plant species such as long lived woody perennials, which are usually outcrossed, these values are higher (Hokanson et al., 1998), as confirmed by our results. According to Powell et al. (1996), expected heterozygosity is a good measure of information content and corresponds to the probability that two alleles taken at random from a population can be distinguished using the marker in question. In our study, the average expected heterozygosity (Table 2 ) for all loci was calculated at 0.716 , and this value falls within the range of values being reported for plant SSR studies and is quite similar to the 0.66 value reported by Guilford et al. (1997) in their study of 21 apple cultivars, and the 0.693 value in the study of 66 Malus $\times$ domestica Borkh. accessions reported by Hokanson et al. (1998).

Pears represent an extremely heterogeneous group of species and genotypes, suggesting that their evolution was complex. The evolution of the pears included in our investigation probably involved all types of genetic recombination (self-fertilization, and intra- and interspecific hybridization).

Breeding experience with other genera shows that interspecific hybrids, from the molecular point of view, usually lie somewhere between the parental species, but after several generations of segregation, they usually drift closer to one of them (Simonovik et al., 2007). In the case of pears, if interspecific recombination had occurred between cultivated and wild genotypes, the progeny probably drifted closer to the wild type because wild

applied to 94 pear genotypes. Both molecular marker techniques proved their reliability in assessing genetic relationships among the pear genotypes being studied. All seven SSR S primers produced PCR amplifications that were polymorphic and easily scorable in all accessions included in the study. From this point of view, the SSR markers used appeared to be very informative markers. The average number of alleles detected per locus in our study ranged from 4 to 15 , with a mean value of 9.14 per locus. This value is very similar to the results obtained by Yamamoto et al. (2002b), which got with seven SSR primers an average nine alleles per locus, and Gianfranceschi et al. (1998), where the number of alleles per SSR ranged from 5 to 12 with an average of 8.2. It is known from the literature that cultivars usually have a better chance of surviving

It is very difficult to explain the genetic origin of perry pears. Based on our results (Fig. 5), it is possible to assume that they do not represent an independent species. Their evolution may include five main possibilities:

(a) Cultivated or semicultivated genotypes of $P$. communis (they probably do not exist any more) genetically recombined with $P$. nivalis [cluster II: subclusters 1 and 2 (e.g., accessions 5, 12, and 17)] or P. pyraster [cluster II: subcluster 3 (e.g., 3, 39, and 57)]. Wild $P$. communis should probably be excluded because of the specific nature of perry pears (e.g., the extremely large fruit of some genotypes). 
(b) Backcrosses involving one of the parental species; interspecific hybrids between wild $P$. communis and $P$. nivalis or $P$. pyraster were probably backcrossed to cultivated $P$. communis (e.g., accession $P$. nivalis from cluster II and subcluster 1 was crossed with one of the cultivated or semicultivated $P$. communis genotypes, probably several centuries ago, and one of the vital hybrids was backcrossed to another cultivated or semicultivated genotype of $P$. communis). Cultivated genotypes of $P$. communis included in the investigation are relatively young and therefore we could not assume that they participated in the formation of perry pears.

(c) Involvement of a third species, probably after many generations of self-fertilization, sib-recombination, and/or crossing among individuals belonging to the same interspecific combination; e.g., $P$. nivalis (cluster II: subcluster 1; accession 71 was crossed with a cultivated genotype of $P$. communis, and after several generations of seed and vegetative propagation associated with artificial selection, one of the plants with several improved characteristics was crossed with $P$. pyraster from cluster II: subcluster 3; accession 9).

(d) Genetic recombination involving two different interspecific hybrids such as $(P$. communis $\times P$. pyraster $) \times(P$. communis $\times P$. nivalis); e.g., a cultivar of cultivated or semicultivated $P$. communis was crossed with $P$. pyraster (accession 57) from cluster II: subcluster 3; in the same region, another or the same genotype of a cultivated or semicultivated $P$. communis was crossed with $P$. nivalis (accession 60 ) from cluster II: subcluster 2; two vital hybrid plants intercrossed and one of the most desired and productive individuals was multiplied as a perry pear cultivar.

(e) Backcrosses of tri-species hybrids with cultivated or semicultivated $P$. communis. A plant obtained from possibility "c" was grown close to cultivated or semicultivated genotypes of $P$. communis, enabling the genetic recombination (backcross). Some of the offspring individuals attracted local growers because of bigger fruit or other desired agronomical traits, and were multiplied vegetative as new cultivars.

$P$. communis, $P$. nivalis, and $P$. pyraster are allogamous and predominately entomophilies species. During evolution, crosses among them probably occurred and one of the results is the perry pear group. To obtain additional information regarding the role of each of the wild species (i.e., $P$. nivalis and $P$. pyraster) in the evolution of perry pears, it would be necessary to include in investigation more genotypes, especially of the wild species. It would also be good to define the reference genotype of $P$. nivalis and to involve more genetically inherited morphological traits (e.g., fruit height-fruit stalk ratio, seed length-width ratio, shape of cotyledons after germination, and shape of the first true leaves). Another question that has to be answered is the level of cross-(in)compatibility among the involved pears species and various groups of perry pears. The best way to find the exact answer is to conduct a semidiallel cross, which should involve as many genotypes as possible, and to count the number of viable seeds obtained.

This study indicates that the germplasm of $P$. nivalis is often present in Slovenia, but not as a botanically "pure" species. $P$. nivalis is associated with several taxonomic problems. When searching for "reference" trees, we faced serious difficulties. For the determination, we used several keys; the most useful was that published by Jacquin (1774). However, it was not possible to find a tree that could be considered a typical $P$. nivalis according to this author's botanical descriptors. Even the tree in the Botanical Garden of the University of Vienna, which was included in our study, differed in several traits. In the dendrogram, it was placed in the cluster I characterized by dominant $P$. communis germplasm.

The germplasm of $P$. pyraster was found to be much less distinctive than we had assumed. There may be several reasons for this. The investigation included a limited number of sampled trees, the sampling did not cover all regions, and only a few trees represented typical wild $P$. pyraster genotypes. Another reason could be the unclear taxonomic distinction between $P$. pyraster, $P$. nivalis, and wild $P$. communis.

The molecular analyses applied enabled us to place some of the unidentified genotypes in known cultivar groups. In some cases, the genetic differences were so small that it was possible to assume that the samples belonged to the same cultivar and could be considered as subclones.

\section{Literature Cited}

Botstein, D., R.L. White, M. Skolnick, and R.W. Davis. 1980. Construction of genetic linkage map in man using restriction fragment length polymorphisms. Amer. J. Hum. Genet. 32:314-331. Botta, R., A. Akkak, G. Me, L. Radicati, and V. Casavecchia. 1998. Identification of pear cultivars by molecular markers. Acta Hort. 457:63-70.

Cerezo, M. and R. Socias. 1989. Isoenzymatic variability in pear pollen. Acta Hort. 256:111-118.

Challice, J.S. and M.N. Westwood. 1973. Numerical taxonomic studies of the genus Pyrus using both chemical and botanical characters. Bot. J. Linn. Soc. 67:121-148.

Dice, L.R. 1945. Measures of the amount of ecologic association between species. Ecology 26:297-302.

Doyle, J.J. and J.L. Doyle. 1987. A rapid DNA isolation procedure for small quantities of fresh leaf tissue. Phytochem. Bul. 19:11-15.

Ghosh, A., L.N. Lukens, D.M. Hunter, and J.N. Strommer. 2006. European and Asian pears: Simple sequence repeat - polyacrylamide gel electrophoresis - based analysis of commercially important North American cultivars. HortScience 41:304-309.

Gianfranceschi, L., N. Seglias, R. Tarchini, M. Komjanc, and C. Gessler. 1998. Simple sequence repeats for the genetic analysis of apple. Theor. Appl. Genet. 96:1069-1076.

Grill, D. and H. Keppel. 2005. Alte Apfel- und Birnensorten für den Streuobstbau. Leopold Stocker Verlag, Graz, Austria.

Guilford, P., S. Prakash, J.M. Zhu, E. Rikkerink, S. Gardiner, H. Bassett, and R. Forster. 1997. Microsatellites in Malus $\times$ domestica (apple): Abundance, polymorphism and cultivar identification. Theor. Appl. Genet. 94:249-254.

Handlechner, G. and M. Schmidthalter. 2007. Die Mostbirnen Sortenraritäten. Verein Neue alte Obstsorten, Amstetten, Austria.

Hartmann, W. 2003. Farbatlas Alte Obstsorten. Verlag Eugen Ulmer, Stuttgart, Germany.

Hemmat, M., N.F. Weeden, and S.K. Brown. 2003. Mapping and evaluation of Malus $\times$ domestica microsatellites in apple and pear. J. Amer. Soc. Hort. Sci. 128:515-520.

Hokanson, S.C., A.K. Szewc-McFadden, W.F. Lamboy, and J.R. McFerson. 1998. Microsatellite (SSR) markers reveal genetic identities, genetic diversity and relationships in a Malus $\times$ domestica Borkh. core subset collection. Theor. Appl. Genet. 97:671-683.

International Union for the Protection of New Varieties of Plants (UPOV). 2000. Guidelines for the conduct of test for distinctness, uniformity and stability, pear (Pyrus communis L.), TG/15/3, 200004-05. 3 Nov. 2008. <http://www.upov.int/en/publications/tg-rom/ tg015/tg_15_3.pdf>.

Jacquin, N.J. 1774. Florae Austriace. Icones et descriptiones II., Vienna, Austria. 
Jogan, N., T. Bacic, B. Frajman, I. Leskovar-Stamcar, D. Naglic, A. Podobnik, B. Rozman, S. Strgulc-Krajsek, and B. Trcak. 2001. Gradivo za atlas flore Slovenije. Center za kartografijo favne in flore. Miklavz na Dravskem polju, Slovenia.

Kessler, H. 1948. Birnensorten der Schweiz. Buchverlag Verbandsdruckerei, Bern, Switzerland.

Lee, G.P., C.H. Lee, and C.H. Kim. 2004. Molecular markers derived from RAPD, SCAR, and the conserved $18 \mathrm{~S}$ rDNA sequences for classification and identification in Pyrus pyrifolia and P. communis. Theor. Appl. Genet. 108:1487-1491.

Löschnig, J., H.M. Müller, and H. Pfeiffer. 1912. Empfehlenswerte Obstsorten, Normalsortiment für Niederösterreich. W. Frick, Wien, Austria.

Lucke, R., R. Silbereisen, and E. Herzberger. 1992. Obstbäume in der Landschaft. Verlag Eugen Ulmer, Stuttgart, Germany.

Marshall, T.C., J. Slate, L. Kruuk, and J.M. Pemberton. 1998. Statistical confidence for likelihood-based paternity inference in natural populations. Mol. Ecol. 7:639-655.

Monte-Corvo, L., L. Goulao, and C. Oliveira. 2002. Discrimination of pear cultivars with RAPD, AFLP and ISSR. Acta Hort. 596:187191.

Monte-Corvo, L., L. Cabrita, C. Oliveira, and J. Leitao. 2000. Assessment of genetic relationships among Pyrus species and cultivars using AFLP and RAPD markers. Genet. Resources Crop Evol. 47:257-265.

Morgante, M., A. Rafalski, P. Biddle, S. Tingey, and A.M. Olivieri. 1994. Genetic mapping and variability of seven soybean simple sequence repeat loci. Genome 37:763-769.

Oliveira, C.M., M. Mota, L. Monte-Corvo, L. Goulao, and D.M. Silva. 1999. Molecular typing of Pyrus based on RAPD markers. Scientia Hort. 79:163-174.

Perrier, X. and J.P. Jacquemoud-Collet. 2005. DARwin-5.0. Dissimilarity analysis and representation for Windows. User's manual. Centre de cooperation internationale en recherché agronomique pour le développement, Montpellier, France.

Petzold, H. 1982. Birnensorten. 2nd ed. Neumann Verlag, Leipzig, Germany.

Pierantoni, L., K.H. Cho, I.S. Shin, R. Chiodini, S. Tartarini, L. Dondini, S.J. Kang, and S. Sansavini. 2004. Characterization and transferability of apple SSRs to two European pear $F_{1}$ populations. Theor. Appl. Genet. 109:1519-1524.

Powell, W., M. Morgante, C. Andre, M. Hanafey, J. Vogel, S. Tingey, and A. Rafalski. 1996. The comparison of RFLP, RAPD, AFLP and SSR (microsatellite) markers for germplasm analysis. Mol. Breed. 2:225-238.
Rehder, A. 1940. Manual of cultivated trees and shrubs, hardy in North America exclusive of the subtropical and warmer temperate regions. 2nd ed. Macmillan, New York.

Saitou, N. and M. Nei. 1987. The neighbor-joining method: A new method for reconstructing phylogenetic trees. Mol. Biol. Evol. 4:406-425.

Santamour, F.S. and P. Demuth. 1980. Identification of callery pear cultivars by peroxidase isozyme patterns. J. Hered. 71:447-449.

Schmidthalter, M. 2001. Die Mostbirnen. Verein Neue alte Obstsorten, Amstetten, Austria.

Shengua, L., F. Chengquan, S. Wenqin, and Z. Feng. 2002. AFLP molecular markers of 10 species of Pyrus in China. Acta Hort. 587:233-236.

Siftar, A. 2008. In Slovenia found traditional pear cultivar to eat processed, p. 391-396. In: M. Hudina (ed.). Zbornik referatov 2. slovenskega sadjarskega kongresa, Krsko, Slovenia.

Simonovik, B., A. Ivancic, J. Jakse, and B. Bohanec. 2007. Production and genetic evaluation of interspecific hybrids within the genus Sambucus. Plant Breed. 126:628-633.

Teng, Y., K. Tanabe, F. Tamura, and A. Itai. 2002. Genetic relationships of Pyrus species and cultivars native to East Asia revealed by randomly amplified polymorphic DNA markers. J. Amer. Soc. Hort. Sci. 127:262-270.

Terpó, A. and J. do Amaral Franco. 1968. Pyrus L., p. 65-66. In: T.G. Tutin (ed.). Flora Europea, Vol. 2, Cambridge University Press, Cambridge, UK.

Volk, G.M., C.M. Richards, A.D. Henk, and A.A. Reilley. 2006. Diversity of wild Pyrus communis based on microsatellite analyses. J. Amer. Soc. Hort. Sci. 131:408-417.

Wagner, H.W. and K.M. Sefc. 1999. IDENTITY 1.0. Center for Applied Genetics, University of Agricultural Sciences, Vienna, Austria.

Westwood, M.N. 1982. Pear germplasm of the new national clonal repository: Its evaluation and use. Acta Hort. 124:57-66.

Wünsch, A. and J.I. Hormaza. 2007. Characterization of variability and genetic similarity of European pear using microsatellite loci developed in apple. Scientia Hort. 113:37-43.

Yamamoto, T., T. Kimura, M. Shoda, Y. Ban, T. Hayashi, and N. Matsuta. 2002a. Development of microsatellite markers in the japanese pear (Pyrus pyrifolia Nakai). Mol. Ecol. Notes 2(1):14-16. Yamamoto, T., T. Kimura, Y. Sawamura, K. Kotobuki, Y. Ban, T. Hayashi, and N. Matsuta. 2001. Characterization and transferability of apple SSRs to two European pear $\mathrm{F}_{1}$ populations. Theor. Appl. Genet. 102:865-870.

Yamamoto, T., T. Kimura, Y. Sawamura, T. Manabe, K. Kotobuki, T. Hayashi, Y. Ban, and N. Matsuta. 2002b. Simple sequence repeats for genetic analysis in pear. Euphytica 124:129-137. 